\title{
Janis Augsburger
}

\section{Masochizmy. Mitologizacja jako estetyka kryzysu w twórczości Brunona Schulza*}

\begin{abstract}
Augsburger Janis, Masochizmy. Mitologizacja jako estetyka kryzysu w twórczości Brunona Schulza [Masochisms. Mythologizing as an Aesthetics of Crisis in the Work of Bruno Schulz]. „Przestrzenie Teorii” 15. Poznań 2011, Adam Mickiewicz University Press, pp. 283-305. ISBN 978-83-232-2293-4. ISSN 1644-6763.

The study Masochisms. Mythologizing as an Aesthetics of Crisis in the Work of Bruno Schulz, parts of which have been translated below, presents the thesis that in the work of B. Schulz the phenomenon of mythologizing is connected with masochism - a concept conceived of as a historical, cultural and aesthetic interpretative category. The combination of the two phenomena makes it possible to notice some relationships between Schulz's literary and graphic works which have not been recognized yet. The author discusses some psychoanalytical, sociological, historical and philosophical notions of masochism applicable to a literary text. She tries to describe the "masochistic aesthetics" appearing in Schulz's short stories (on the narrative level: lack of motion, suspense, tension) and in his graphics (theatricalization, lack of eye contact between the figures) and shows how this aesthetics integrates the prose of Schulz, his Idolatrous Book and his illustrations for the short story The Book.
\end{abstract}

\section{Wstęp: Obrazy „bankructwa realności”}

\begin{abstract}
Jaki jest sens tej uniwersalnej deziluzji rzeczywistości - nie potrafie powiedzieć. Twierdze tylko, że byłaby ona nie do zniesienia, gdyby nie doznawała odszkodowania $w$ jakiejś innej dymensji. W jakiś sposób doznajemy głębokiej satysfakcji z tego rozluźnienia tkanki rzeczywistości, jesteśmy zainteresowani w tym bankructwie realności ${ }^{1}$.
\end{abstract}

Tytuł niniejszej książki przekazuje pewną tezę. Chodzi o wymiary masochizmu w twórczości polsko-żydowskiego artysty i pisarza z Galicji Brunona Schulza - a dokładniej: o założenie, że masochizm, ujmowany w różnych wymiarach, stanowi strukturę przewodnią w rozumieniu jego dzieła. Wprawdzie sam Schulz w autokomentarzach i pismach krytycz-

* Autorka przekładu, redakcja „Przestrzeni Teorii” i Wydawnictwo Naukowe UAM serdecznie dziękują Wydawnictwu Wehrhahn z Hanoweru za wyrażenie zgody na druk tego tekstu.

1 Bruno Schulz do Stanisława Ignacego Witkiewicza, [w:] B. Schulz, Opowiadania. Wybór esejów i listów, oprac. J. Jarzębski, Wrocław-Warszawa-Kraków-Gdańsk-Łódź 1989 , s. 445. 
nych nie posługuje się pojęciem masochizmu, tym częściej za to sięga do kategorii mitu i mityzacji. Jednym z celów tej książki jest udowodnienie, że oba te pojęcia wiążą się ze sobą oraz pokazanie, w jaki sposób tak się dzieje. Jak pisze Schulz, w jego opowiadaniach chodzi o „wydobyci[e] dziejów pewnej rodziny [...] - nie z ich realnych elementów, wydarzeń, charakterów czy losów prawdziwych, lecz poszukując ponad nimi mitycznej treści, sensu ostatecznego owej historii"2.

Powiązanie twórczości Schulza z pojęciem masochizmu uzasadnia cykl grafik powstały na początku roku 1920: Xięga bałwochwalcza, o niezwykle wyrazistej, przesyconej erotyką tematyce masochistycznej. Opowiadania Schulza, opublikowane przeszło dekadę później, nie krążą już tak blisko i obsesyjnie wokół tej tematyki; mimo to występują w nich liczne nawiązania do wspomnianych grafik, wymagające dokładniejszej analizy. Ponadto w twórczości Schulza obecne są estetyczne tendencje dezintegracji rzeczywistości i tożsamości, różnorodne formy przekraczania granic $\mathrm{w}$ pisarstwie, które naświetlają charakterystyczny dla tego autora motyw literacki i skłaniają do refleksji nad strukturami masochizmu - ten zaś z kolei odsyła do niejasnych granic tożsamości i płynnych form świata rzeczywistego. Jednocześnie wspomniane tendencje dezintegracji wydobywają na światło dzienne proces poszukiwania przekształconej jedności, integralności i tożsamości.

Dzieło Schulza odkryto w Niemczech ponownie dopiero w latach sześćdziesiątych. Jego opowiadania odbierane są w kategoriach literatury powszechnej, one też w recepcji światowej budzą zainteresowanie większe niż twórczość plastyczna, pod względem objętościowym obszerniejsza od pisarskiej. Ponieważ jednak w prozie moment masochistyczny ulega przekształceniu w retorykę mitologizacji, nikt dotąd nie wpadł na pomysł, aby poprzez dokładną analizę grafik z Xięgi bałwochwalczej w kontekście rozbudowanego pojęcia masochizmu uważniej przyjrzeć się związkom między twórczością plastyczną i prozatorską Schulza. Wyjątkiem jest Artur Sandauer. We wstępie do pierwszego powojennego wydania prozy Schulza (1957) krytyk - nie pisząc zresztą o samych grafikach łączy masochizm z doświadczeniem społecznej degradacji, będącym udziałem polskich Żydów w okresie międzywojennym. Sandauer ujmuje masochizm jako transformację historycznego cierpienia w estetyczną rozkosz.

2 B. Schulz, Exposé o „Sklepach cynamonowych”, przeł. J. Ficowski, [w:] J. Ficowski, Regiony wielkiej herezji i okolice. Bruno Schulz $i$ jego mitologia, Sejny 2002, s. 165. W tłumaczeniu pominięto przypisy Autorki odnoszące się do faktów i źródeł w polskiej „schulzologii” dostatecznie znanych, skierowanych raczej do czytelników niemieckich (przyp. tłum.). 
Rozważania prezentowane $\mathrm{w}$ tej książce biorą swój początek $\mathrm{z}$ tej właśnie koncepcji. Refleksje Sandauera potwierdzają podejście metodologiczne, aby masochizm rozumieć jako zjawisko wielowymiarowe, którego absolutnie nie należy sprowadzać li tylko do pewnej preferencji erotycznej. Ponadto w kategorii masochizmu mieści się też kwestia znaczenia, jakie Schulz przywiązuje do sztuki, a które należałoby określić mianem niemalże religijnego. Stąd teza, iż masochizm oznacza u Schulza proces poszukiwania remedium na historyczne i indywidualne rozłamy - proces, który początkowo ulega transformacji w wymiar cielesny, następnie zaś w dualizm płci. Twórczość artystyczna - „mityzacja rzeczywistości” - sama w sobie nie stanowi jeszcze takiego remedium, ale jej funkcja transcendentna wskazuje na możliwość reintegracji, nieustannie odsuwanej w czasie. To odsunięcie w przyszłość jawi się jako centralna estetyczna funkcja masochizmu w twórczości Schulza.

Proces ten można prześledzić $\mathrm{w}$ interpretacji - podejmowanej wciąż od nowa - w której temat rozczarowania religią, daremnego oczekiwania miłości i akceptacji, a jednocześnie wciąż żywej nadziei na osiągnięcie integralności zostaje przeniesiony w sferę transcendencji - co pokazuje, iż nasycenie sztuki znaczeniem quasi-religijnym oraz (nieudana) hipostazja egzystencji artystycznej stają się wybawieniem z konfliktów historycznych. Fakt zaś, iż owa egzystencja artystyczna i świat fantazji pokazane są u Schulza explicite jako rekompensata skomplikowanego dziejowego doświadczenia degradacji, nieodparcie nasuwa myśl, by proces mityzacji rzeczywistości powiązać ze strukturą masochizmu. Rezultat tej operacji jest $\mathrm{w}$ moim przekonaniu otwarty na krytykę bądź konkretyzację - należy go bowiem rozumieć jako perspektywę poszerzającą względnie integrującą dotychczasowe badania nad twórczością autora Sklepów cynamonowych.

W interpretacji dzieł Schulza często przywołuje się daty i fakty z jego biografii. Niewątpliwy kontekst autobiograficzny wczesnych grafik i prozy poniekąd usprawiedliwia takie podejście. Paralele między ojcem pisarza - Jakubem Schulzem a postacią Jakuba z opowiadań są równie jednoznaczne, co autoportrety artysty obecne w Xiędze bałwochwalczej. Niemniej jednak wydaje się, że Schulz może właśnie z uwagi na ów jawny autobiografizm żywił obiekcje wobec procesu interpretowania ${ }^{3}$. Interpretacja nie tylko bowiem redukuje zamierzoną przez Schulza mitologizującą funkcję dzieła sztuki, ale też nader często oznacza „wchłonięcie”, „zagarnięcie” i niezrozumienie komentowanego dzieła przez interpretatora.

3 List do S.I. Witkiewicza: „Sądzę, że zracjonalizowanie widzenia rzeczy tkwiącego w dziele sztuki równa się zdemaskowaniu aktorów, jest końcem zabawy, jest zubożeniem problematyki dzieła”. B. Schulz, Opowiadania..., dz. cyt., s. 444. 
Nasuwa się pytanie, czy prezentowana tu analiza również nie sprowadza się do postawy zawłaszczającej - pozbawionej respektu, niszczącej „Obce” i splatającej je z własnym doświadczeniem? Jak uzasadnić tę interpretację - i czy w ogóle uda się znaleźć odpowiedzialne podejście, które nie zagarnie „Innego”, tylko pozwoli mu istnieć jako coś całkiem własnego i samoistnego? Niniejsza praca była początkowo jedynie próbą; z czasem uległa przymusowi wewnętrznej koherencji, nabrała tendencji do systemowości (a więc do odgraniczenia wobec innych sposobów odczytań), a także do autopoetycznego generowania się według samodzielnie znalezionych (czy też zaprojektowanych?) kryteriów. Systemowość, pojęcia bazujące jedne na drugich - wszystko to zadaje gwałt estetyce, na której tak zależało Schulzowi: strumieniowi zjawisk, przypadkowości, inkoherencji. Rodzi to pewien dylemat metodologiczny.

Interpretacja, która nie chce niczego zawłaszczać, może tę tendencję do systemowości sugerować, zachowując jednak powściągliwość i dopuszczając do głosu same zjawiska (tekst, obrazy, historię). Ambicja, by twórczość Schulza uczynić zjawiskiem zrozumiałym, ma i tak charakter totalitarny. Wycofanie się na pozycję konsekwentnego sceptycyzmu oznaczałoby jednak pochopne poddanie się milczącej kontemplacji, zasysającej sile regresywnego prazrozumienia. Siłę taką na pewno chciał stworzyć Schulz; jednak podążenie za jego fascynacją powinno oznaczać „rozjaśnienie” oddziaływania dzieła - co może faktycznie powodowałoby „zdemaskowanie aktorów", którego obawiał się twórca Wiosny, i potwierdzałoby jego obiekcje.

$\mathrm{Na}$ konferencji w Leuven poświęconej Schulzowi ${ }^{4}$ Krzysztof Stala sformułował trafną uwagę metodologiczną: badania nad Schulzem (z natury rzeczy stawiające opór owej sile zasysającej w milczenie) wykazują tendencję, aby jego twórczość wykorzystywać jako pryzmat, przez który wejrzeć można w epokę i problematykę estetyczną europejskiego modernizmu. Twórczość Schulza staje się hermeneutycznym kluczem do zrozumienia skomplikowanej, wyrugowanej epoki polskiego dwudziestolecia. Skoro zaś metoda autobiograficzna napotkała swoje granice, obiecującą perspektywą badawczą wydaje się poszukiwanie wciąż nowych kontekstów interpretacyjnych, grożących jednak „pochłonięciem” dzieła. „Winę” za to ryzyko ponosi zreszta eklektyczna gra nastawiona na dezorientacje czytelnika, inscenizowana przez samego Schulza za sprawą nawiązań do różnorodnych kontekstów, wzorców i tradycji.

$$
\text { [...] }
$$

4 "The World of Bruno Schulz - Bruno Schulz and the World: Influences, Similarities, Reception", 25-26 maja 2007, Katolieke Universiteit Leuven, Belgia. Referaty zebrano w tomie: (Un)masking Bruno Schulz: New Combinations, Further Fragmentations, Ultimate Reintegrations (Studies in Slavic Literature \& Poetics), eds D. de Bruyn, K. Van Heuckelom, Amsterdam-New York 2009. 


\section{Masochizm w znaczeniu rozszerzonym}

Wypadałoby stworzyć takie pojęcie masochizmu, które ogarniałoby oba jego wymiary: konflikt cielesny i tęsknotę za wybawieniem poza cielesnością 5 - pojęcie uwzględniające wymiar zarówno erotyczny, jak i społeczny, które można zastosować do przedstawień artystycznych. W tym celu konieczny jest krótki rys historyczny pojęcia masochizmu, ponieważ samo zjawisko podlega zmiennym osądom naukowym, przede wszystkim zaś normatywnym ocenom społecznym. Na przykładzie tych właśnie ocen można pokazać zasadniczą strukturę masochizmu - w taki sposób, aby charakterystyczna dlań relacja nierównowagi dała się łatwiej przełożyć na konstelacje niekoniecznie erotyczne.

$[\ldots]$

\section{Znieruchomienie i napięcie. Masochistyczna estetyka}

Punktem wyjścia koncepcji estetyki masochistycznej stał się szkic Gilles'a Deleuze'a na temat opowiadania Leopolda von Sacher-Masocha Wenus $w$ futrze ${ }^{6}$. Wpisuje się on $\mathrm{w}$ refleksję Theodora Reika ${ }^{7}$, którego obserwacje Deleuze poszerza: kwestionuje przekonanie o jedności i komplementarności sadyzmu i masochizmu (,Sadysta i masochista ewidentnie muszą się spotkać”), aby opisać samodzielne „uniwersum masochizmu"8.

Wychodząc od analizy tekstów literackich, Deleuze przytacza przekonujące argumenty przeciwko tezie o wzajemnym uzupełnianiu się obu predyspozycji. Najprostszy z nich to refleksja, że sadystyczny dręczyciel

5 Autorka nawiązuje z jednej strony do historyczno-socjologicznego ujęcia masochizmu według Sandauera, z drugiej - do interpretacji Władysława Panasa, który pisze o masochizmie w kontekście religijnym: odkupienia grzechów i nadziei na zbawienie. W ten sposób w pojęciu masochizmu mieściłaby się zarówno problematyka alienacji i historycznych konfliktów, jak i mistycznej tęsknoty za transcendencją (przyp. tłum.).

${ }^{6}$ G. Deleuze, Sacher-Masoch und der Masochismus (posłowie do wydania: L. von Sacher-Masoch, Venus im Pelz, Frankfurt am Main 1997).

7 Niemiecki psycholog, jako pierwszy (1940) dostrzegł w masochizmie zjawisko społeczno-kulturowe, a nie tylko biologiczne; zwrócił uwagę, że tendencje masochistyczne wykazują także mężczyźni - wbrew przekonaniu, jakoby masochizm był naturalną predyspozycją kobiety (przyp. tłum.).

${ }^{8}$ G. Deleuze, Sacher-Masoch und der Masochismus, dz. cyt., s. 169: „Przekonanie o sadomasochistycznej jedności miało bardzo niekorzystny wpływ na odbiór pisarstwa Sacher-Masocha. Autor ten nie tylko popadł w niezasłużone zapomnienie, ale ucierpiał wskutek nieuzasadnionego przeświadczenia o komplementarności i dialektycznej jedności sadyzmu i masochizmu. A przecież czytelnik Masocha od początku czuje, że jego uniwersum nie ma nic wspólnego ze światem markiza de Sade’a” (tłum. K.L.). 
nie znajduje radości w kimś, kto chętnie cierpi. Podobnie postacie Sacher-Masocha nie zaakceptowałyby prawdziwego kata, niepodlegającego ich kontroli. Wanda z Wenus $w$ futrze nie może być sadystką. Do swej roli podchodzi w sposób ambiwalentny. Przyjmuje ją z ciekawości, ba - wręcz $\mathrm{z}$ miłości, ale nie $\mathrm{z}$ wrodzonego sadyzmu. Istotne cechy treści masochistycznych w opowiadaniu Sacher-Masocha to: efekt suspensu, masochistyczny kontrakt oraz skłonności „dydaktyczne” masochisty (który musi kobietę najpierw przekonać do roli dręczycielki).

Inaczej niż Reik i Freud, Deleuze zauważa, że owa idealna kobieta wcale nie reprezentuje ojca. Inscenizowany dramat ma zatem tylko po części charakter edypalny. Jeśli ojciec w ogóle w nim występuje, to najwyżej w samym masochiście, którego wyobraźnia krąży wokół paktu z idealną matką. Pogarda i krzywda zadawana przez matkę kieruje się nie tyle przeciwko masochiście, ile tym elementom jego osobowości, które są identyczne z ojcem - obiektem ataku jest „podobieństwo do ojca”. Karzaca kobieta ma unieszkodliwić cechy syna upodabniające go do ojca tak, aby synowi (masochiście) utorować drogę do jedności z matką (idealną kobietą). Aby zyskać pewność, że tę kobietę faktycznie posiądzie, masochiście potrzebny jest kontrakt. Jego partnerka wykazuje cechy kobiece, macierzyńskie. [...]

Deleuze w swym ujęciu psychoanalitycznym odnosi zjawisko masochizmu do struktury ego - superego: jego zdaniem, sadyzm i masochizm stanowią zaburzenia ego, dysproporcje w strukturze psychiki warunkujące formy estetyczne ich przedstawienia. U de Sade'a sadysta (sadystka) stosuje „szkolny”, logiczno-chłodny, przemożny język argumentacji i demonstracji, który według Freuda jest rolą superego. Zdaniem Deleuze'a, sadyzm byłby więc objawem nadmiernego rozrostu superego. A zatem to nie brak superego powoduje chaotyczne uleganie popędowi i motywuje sadystę do działania; siłą sprawczą jest samo superego i jego tyrański charakter („Chodzi o wykazanie, że sprawowanie władzy jest tożsame z logicznym dowodzeniem faktów”) ${ }^{9}$. I odwrotnie: u masochisty całkowicie brak superego; masochista ma wyłącznie narcystyczne ego wybujałe do tego stopnia, że funkcje superego widzi wyłącznie ucieleśnione w innych osobach. Deleuze odczytuje masochizm jako historię „opowiadającą o tym, jak własne superego uległo zniszczeniu, kto je zniszczył i co z tego zniszczenia powstało"10. Przeciwstawia się w ten sposób Freudowi, który w masochizmie moralnym widział wewnątrzpsychiczną konstelację zbyt surowego superego oraz ego, które oczekuje kary. Natomiast zdaniem Deleuze'a, pierwotną przyczyną masochistycznych zaburzeń osobowości jest narcyzm - nadmierna obsada libidynalna własnego ego.

9 Tamże, s. 175.

10 Tamże, s. 274. 
Tak rozumując, Deleuze przypisuje masochizmowi i sadyzmowi wspólne źródło umieszczone w instancji superego, co kłóci się nieco z ambicją wykazania asymetrycznej różnicy między sadyzmem a masochizmem.

W refleksję o wspólnych korzeniach obu tendencji wpisują się też uwagi francuskiego filozofa na temat powtórzenia i popędu śmierci. Żonglując pojęciami bólu i rozkoszy, Deleuze trafnie zauważa wspólną formę sadyzmu i masochizmu: „Eros zostaje odseksualniony i zabity po to, by Tanatos mógł ulec reseksualizacji”. Obsesyjne powtarzanie tego, co destrukcyjne, niszczące, skazane na klęskę (o czym mówił Freud), stanowi zarówno w masochizmie, jak i w sadyzmie specyficzną, zreseksualizowaną formę rozkoszy, jakiej dostarcza Tanatos ${ }^{11}$. Tu jednak Deleuze mija się z celem: nie udaje mu się wykazać, że sadyzm i masochizm to dwie rozłączne, samodzielne formy. [...] A przecież „literatura masochistyczna” różni się od tekstów de Sade’a.

W literackich przedstawieniach masochizmu istotna jest specyficzna technika napięcia, którą cechuje odsunięcie zespolenia seksualnego w czasie i odwrócenie od niego uwagi. Opowiadania Sacher-Masocha ewokują duszną atmosferę, która „rozprzestrzenia się w zastygającym ruchu [...] niczym zbyt ciężkie perfumy"12 i wytwarza „stan absolutnego zawieszenia” czy też „absolutnego oczekiwania”, jak można skonkretyzować moment suspensu. Jak zauważa Deleuze, owo napięcie, które nie daje się rozładować, skłania do przesycenia języka obrazami - nie tylko $\mathrm{w}$ znaczeniu retorycznego przeniesienia, aluzji i metafor; napięcie to wyraża się przede wszystkim na płaszczyźnie narracyjnej jako zastygnięcie, retardacja, znieruchomienie i poza. W tekście Wenus $w$ futrze ważną rolę odgrywają malowidła, portrety i statuy. Otulona futrem Tycjanowska Wenus $z$ lustrem z galerii drezdeńskiej, kontemplująca własne odbicie $\mathrm{w}$ zwierciadle podtrzymywanym przez Amora, wspomniana jest w rozmowie dwóch przyjaciół jako przykład „okrucieństwa towarzyszącego kobiecej piękności"13 [...].

Bierne zachowanie Seweryna - głównego bohatera opowiadania Sacher-Masocha - polega głównie na spoglądaniu, przypatrywaniu się, odwracaniu spojrzeń i snuciu fantazji. Jego wzrok, śledzący obrazy i sceny przede wszystkim oczy Wandy, jej sylwetkę, stroje - jest czymś w rodzaju masochistycznego organu. W jej oczach bohater wypatruje antycypacji

11 Tamże, s. 276.

12 Tamże, s. 189.

13 L. von Sacher-Masoch, Wenus w futrze, Łódź 1989 [tekst według publikacji Wydawnictwa „Kultura i Sztuka”, Lwów 1920, bez nazwiska tłumacza], s. 25-26. Wspomniany obraz Tycjana nie znajduje się w Dreźnie, ale w National Gallery of Art w Waszyngtonie (przyp. tłum.). 
własnego cierpienia, a wielokrotnie wzmiankowana wymiana spojrzeń między postaciami przydaje wydarzeniom psychologicznego ciężaru. Seweryn nie tylko przeżywa spotkania z Wandą jak sceny teatralne; również i inne obserwacje, które wiąże ze swą namiętnością, mają charakter voyeurystyczny. Owa pożądliwa antycypacja cierpienia, wyrażająca się w intensywnej obserwacji, odcina masochistycznego kochanka od rzeczywistości. Bohater definiuje znaczenie tego, co widzi - teatr świata i relacji międzyludzkich - jako inscenizację przygotowaną specjalnie dla niego. Tendencja ta da się wytłumaczyć narcyzmem masochisty - cechą, którą można rozumieć jako brak umiejętności nawiązywania realnych stosunków z obiektem własnych pragnień. Masochista patrzy na świat zewnętrzny pożądliwym wzrokiem, a frustracja, której źródłem jest ów świat oraz wolność i suwerenność drugiej osoby, w jego wyobraźni zostaje przeinterpretowana $\mathrm{w}$ rozkosz i spotęgowana przez własną inscenizację. Faktyczna wolność partnera ma znaczenie marginalne - ważne, by jako obiekt pożądania był on częścią „inscenizowanego kina” masochisty.

Nie dziwi zatem dążenie masochizmu do przedstawień w sztukach wizualnych. Słowo i obraz poddają się sile narcystycznej wyobraźni. Zranienie, pod którego wpływem ego uznałoby zasadę realizmu, może wówczas zostać swobodnie opracowane. Masochistyczna sztuka przekształca narcystyczny ból, mający swe źródło w wolności drugiej osoby, w zjawisko, którego masochista sam sobie życzy i które sam kształtuje. Uniwersum sztuki daje schronienie nadmiernie wybujałemu ego, postrzegającemu swe relacje ze światem zewnętrznym jedynie w kategoriach zagrożenia i bólu. Typowym przykładem tej cechy „estetyki masochistycznej” jest asymetria spojrzeń, unikanie kontaktu wzrokowego między kobietą a mężczyzną, tak wyraźne w Xiędze bałwochwalczej. [...]

Germanista John Noyes w swojej interpretacji Wenus $w$ futrze stwierdził, że opisy spojrzeń wymienianych przez Wandę i Seweryna odpowiadają sadomasochistycznemu charakterowi ich relacji14. Spojrzenia Wandy opisywane są niemalże obsesyjnie i wyrażają całą gamę uczuć między namiętnością a lodowatym chłodem, niezwykle rzadko natomiast napotykają symetrycznie „męczeński” wzrok Seweryna. [...]

Pojęcie estetyki masochistycznej wprowadza Gaylyn Studlar w pracy In the Realm of Pleasure. Von Sternberg, Dietrich and the Masochistic Aesthetic (1988), nie bez powodu opierając się na przykładach ze sztuki filmowej. Badaczka polemizuje z tezami Laury Mulvey, że kino hollywoodzkie nastawione jest na sadystyczne, voyeurystyczne pragnienia

14 Zob. J. Noyes, Der Blick des Begehrens, „Acta Germanica” 1988, 19. Cyt. za: M. Gratzke, Liebesschmerz und Textlust. Figuren der Liebe und des Masochismus in der Literatur, Würzburg 2000, s. 49-50. 
męskiej publiczności, a filmowe postaci kobiet są fetyszyzowane i skazane na zniszczenie ${ }^{15}$. Studlar próbuje zrelatywizować ten pogląd na podstawie filmów Josefa von Sternberga z Marleną Dietrich oraz uwag Deleuze'a.

Studlar zauważa w omawianych filmach odwrotną możliwość: mężczyzna jako masochistyczny widz zostaje wydany na pastwę spojrzeń filmowej diwy. Mężczyzna cofa się do stanu dziecięcej bezradności, przypomina sobie niegdysiejszą zależność od ciała i wzroku matki, odbieranej jako istota wszechwładna. [...] Zaleta masochistycznej estetyki polegałaby na odmiennym niż tradycyjny obrazie płci męskiej, diametralnie różnym od stereotypu męskości dominującej i sadystycznej16.

Podejście Studlar polega na „Zwrocie symbiotycznym”, jak można by określić odwrót od edypalnego modelu Freuda. Studlar powołuje się na pogląd, że cel masochisty to „podwójna jedność i całkowita symbioza między matką a dzieckiem"17. Istnienie typów seksualności niegenitalnej, przede wszystkim jednak wrażliwy na zaburzenia przebieg procesu męskiej indywiduacji można by pełniej wyjaśnić, analizując pregenitalne stadia dzieciństwa, głównie problemy związku z matką i odłączenia się od niej.

Już Deleuze, pokazując znaczenie różnych obrazów matki u Sacher-Masocha, zwrócił uwage na ambiwalencję postawy masochisty wobec wymarzonej preedypalnej jedności z matką ${ }^{18}$. Wspomniany „zwrot symbiotyczny" skutkuje też nową interpretacją fetyszu: nie jest on już - jak u Freuda - oznaką bojaźliwego wyparcia męskiego lęku kastracyjnego' ${ }^{19}$, lecz może być rozumiany jako obsada libidynalna, która umożliwia utrzymanie w mocy oralnych fantazji o wszechwładzy pochodzących $\mathrm{z}$ wczesnego dzieciństwa. Wizja zjednoczenia matki z dzieckiem (płci męskiej) tworzy przestrzeń dla biseksualnych, niezróżnicowanych typów seksualności, wynikających $\mathrm{z}$ fantastycznego rozmycia granic własnego ciała. Fetyszyzowana kobieta staje się wówczas obiektem tęsknoty, symbolizującym androginiczną całość, integralność i bezpieczeństwo; kobieta to

15 Zob. L. Mulvey, Visual Pleasure and Narrative Cinema, "Screen" 1975, 16.

16 Zob. G. Studlar, Schaulust und masochistische Ästhetik, [w:] Phantom der Lust. Visionen des Masochismus in der Kunst (katalog z wystawy w Grazu, na której prezentowano m.in. wybrane grafiki Schulza - przyp. tłum.), hrsg. P. Weibel, Graz 2003, s. 326-354.

17 Zob. tamże, s. 330.

18 Owa tęsknota za jednością jest zasadniczo ambiwalentna, skoro jednocześnie implikuje rezygnację z własnej niezależności - zob. tamże, s. 328 .

19 Według Freuda fetyszyzowany obiekt „gwarantowałby” własną nienaruszalność i potencję, wymuszając uchwycenie momentu tuż przed ujrzeniem „braku” (zob. S. Freud, Fetischismus, [w:] tegoż, Gesammelte Werke, t. XIV, hrsg. A. Freud i in., Frankfurt am Main 1999, s. 311-317). 
czuła matka-żywicielka, która jednak może tę funkcję odrzucić, pozostawiając dziecko samo sobie - przez co staje się okrutna; taka kobieta karze, odsuwając spełnienie pragnień na później lub też w ogóle go odmawiając (podczas gdy spełnienie masochista odbiera jako potwierdzenie swej władzy). I znów istotne staje się znaczenie kontaktu wzrokowego między kobietą-matką a dzieckiem. W więzi między matką a dzieckiem, typowej dla wczesnego dzieciństwa, intensywny kontakt wzrokowy sygnalizuje właśnie tę jedność. Spojrzenie matki wyraża miłość i troskę, a równocześnie kontrolę i autorytaryzm, pozwalając dziecku poczuć własną bezradność i bierność:

Jeśli powrócimy do fantazji sięgających fazy oralnej, wówczas masochistyczna estetyka będzie sugerować siłę żądania, którego źródłem nie jest kompleks kastracyjny, lecz tęsknota dziecka za szczęśliwą symbiozą, bolesna rozkosz, jaką wywołuje poczucie własnej bezradności i ambiwalentne odczucie na widok własnej matki ${ }^{20}$.

[...]

\section{Nieprzerwana kontynuacja stosunku panowania i poddaństwa}

Można rzec, iż praktyki i wizje sadomasochistyczne powielają społeczne schematy władzy w sferze prywatnej. Według Paula Gebhardta sadyzm i masochizm wynikają bezpośrednio z pewnego klimatu społecznego opartego na ucisku i dominacji, typowego dla porządku społecznego kapitalistycznego Zachodu ${ }^{21}$.

Oba zjawiska to również reakcja, która tę przemoc nie tylko powiela, ale też kompensuje. Agresja powstała z narcystycznych okaleczeń może znaleźć ujście w sadomasochizmie, umiejscowionym w chronionej sferze prywatnej22.

Tę funkcję „seksualności peryferyjnych” podkreśla Peter Gorsen. Jego zdaniem, sadyzm i masochizm to źródła psychicznej kreatywności. Perwersje miałyby jeszcze tę zaletę, że wiążą się z fikcją, grą i rytuałem. Dzięki temu agresja, która inaczej rozprzestrzeniłaby się w obszarze społecznym, podlega kontroli, a kreatywność jest stymulowana ${ }^{23}$. Perwersyjne praktyki seksualne byłyby ponadto legalną strategią terapii umiejęt-

${ }^{20}$ G. Studlar, Schaulust..., dz. cyt., s. 354.

${ }^{21}$ Zob. P. Gebhardt, Fetishism and Sadomasochism, [w:] Dynamics of Deviant Sexuality, ed. J.H. Massermann, New York-London 1969, s. 77-82, cyt. za: M. Gratzke, Liebesschmerz und Textlust..., dz. cyt., s. 17.

22 Zob. P. Gorsen, Psychopathia sexualis und Kunst. Phantasmen der masochistischen Kunst, [w:] Phantom der Lust..., dz. cyt., s. 200-220.

${ }^{23}$ Zob. tamże, s. 201. 
ności wchodzenia w związki emocjonalne, ograniczonej wskutek odniesionych ran psychicznych:

Jeśli proces rozwoju narcystycznego przebiega prawidłowo, jaźń wypełnia się treściami i uczuciami i dopełnia się w harmonijną całość. Jeśli rozwój ten ulegnie zaburzeniu, procesy integracyjne nie przebiegają prawidłowo. Jaźń nie dopełnia się: pozostaje w niej luka, którą perwersyjne przeżycia wypełniają niczym plomba $^{24}$.

Problem reprodukcji przemocy społecznej w masochizmie na przykładzie prozy Sacher-Masocha bada John Noyes. Stawia on tezę, że masochizm austriackiego pisarza stanowi odbicie kryzysu społeczeństwa mieszczańskiego w wielonarodowej Galicji ${ }^{25}$.

Paradoks masochisty polega na tym, że kanalizuje on przemoc społeczną pod postacią prywatnej patologii i prywatnej rozkoszy, które same w sobie tę przemoc kontynuują. Sacher-Masoch projektuje przemoc społeczną na relacje między kobietą a mężczyzną ${ }^{26}$.

Sacher-Masoch - historyk i prawnik - już w swoich pismach uniwersyteckich łączył badania historyczne ze stylem właściwym beletrystyce. Interesowała go historia wielkich mocarstw i barwne postacie rządzących kobiet ${ }^{27}$. Fikcjonalność owych studiów Sacher-Masoch uzasadniał zadaniem historyka, polegającym na odsłanianiu ukrytych motywacji i interesów postaci historycznych. Według Noyesa argumentację tę można odwrócić, dostrzegając w prozie Sacher-Masocha poszerzenie perspektywy historycznej28. W swej obszernej twórczości austriacki pisarz dąży do tego, by opisać „uniwersalność walki” zarówno w sferze politycznej i społecznej, jak i prywatnej29.

24 Tamże, s. 216.

25 J. Noyes, The Importance of the Historical Perspective in the Works of Leopold von Sacher-Masoch, [w:] Modern Austrian Literature, Riverside 1994; tegoż, The Mastery of Submission. Invention of Masochism, London 1997, cyt. za: M. Gratzke, Liebesschmerz und Textlust..., dz. cyt.

${ }^{26}$ M. Gratzke, Liebesschmerz und Textlust..., dz. cyt., s. 31.

27 Jego pierwsze studium historyczne to Powstanie $w$ Gandawie za panowania Karola V (Der Aufstand von Gent unter Karl V., 1857), zaś w roku 1862 ukazał się Upadek Węgier i Maria Austriaczka (Ungarns Untergang und Maria von Österreich).

28 Zob. J. Noyes, The Importance..., dz. cyt., s. 5.

29 Jego pierwsza nowela Opowieść galicyjska (Eine Galizische Erzählung, 1859) poświęcona jest rabacji galicyjskiej z roku 1846. W utworze pt. Emisariusz. Historia galicyjska (Der Emissar. Eine galizische Geschichte, 1863) występują przedstawiciele dwóch grup etnicznych zamieszkujących Galicję: Roman - polski szlachcic, Burg - austriacki urzędnik i Karola - kobieta uosabiajacca polsko-austriacką syntezę. Roman i Burg reprezentują dwa typy męskości skonfrontowane później w Wenus w futrze: jeden to „Grek”, typ praktyczny, męski, drugi - wrażliwy marzyciel, masochista (zob. J. Noyes, The Importance..., dz. cyt., s. 9). 
Nowością w pisarstwie Sacher-Masocha jest przekonanie, że rodzina i sfera intymna nie są już oazą bezpieczeństwa i wytchnienia od żądań społeczeństwa stojącego „na zewnątrz”, lecz miejscem kontynuacji jego konfliktów. Wynika stąd odrzucenie humanistycznej wiary w postęp: ludzkość, zamiast dążyć ku coraz wyższym postaciom szczęścia, porusza się w odwiecznej pętli cierpienia, z której nie sposób się wyswobodzić (tu znów istotny jest moment powtórzenia). Dla Sacher-Masocha cierpienie to „najbardziej podstawowe i powtarzalne ludzkie doświadczenie”, którego ilustracją są dlań dzieje świata. Natomiast masochistyczna narracja to próba, aby - podobnie jak w przypadku ironii - w cierpieniu, które wciąż powraca, odnaleźć jeszcze jakąś formę przyjemności ${ }^{30}$.

\section{Masochizm jako próba ocalenia własnego Ja}

Podejście teoretyczne łączące problem społecznego znaczenia masochizmu (jako krytyki stosunku władzy i podległości) z jego funkcją dla równowagi psychicznej proponuje nowojorska psychoanalityk Jessica Benjamin $^{31}$. Bada ona psychogenezę masochizmu oraz zjawiska wyobcowania, reifikacji i fetyszyzacji, które można powiązać z masochistycznymi inscenizacjami. Badaczka skupia się na pytaniu, w jaki sposób prywatne „perwersje” korelują z podziałem władzy w przestrzeni społecznej.

Benjamin ujmuje sadyzm i masochizm jako wyobcowane, zdeformowane postacie miłości, powstałe wskutek nierozwiązanego konfliktu między koniecznością obrony własnej jaźni a potrzebą obecności drugiej osoby. Badaczka wpisuje się w nurt teoretyczny wychodzący z założenia, że dla zaburzeń rozwojowych i problemów w nawiązywaniu relacji w wieku dorosłym decydujące znaczenie ma charakter związku dziecka z matką we wczesnym dzieciństwie. Według Benjamin niemowlę nie jest jednak biernym, roszczeniowym monstrum wierzącym we własną omnipotencję (Freud mówił o polimorficznej perwersyjności niemowlęcia), matka zaś jedynie obiektem jego władczych popędów; przeciwnie: już w najwcześniejszych stadiach rozwoju człowieka uwidacznia się dążenie zarówno do indywiduacji, jak i interakcji z innymi ${ }^{32}$.

30 Zob. tamże, s. $13-14$.

31 J. Benjamin, The Bonds of Love, New York 1988 (wyd. niemieckie: Die Fesseln der Liebe. Psychoanalyse, Feminismus und das Problem der Macht, Frankfurt am Main 1993).

32 Benjamin powołuje się na prace $\mathrm{z}$ dziedziny psychologii rozwojowej, m.in. Johna Bowlby'ego i Daniela Sterna, którzy pokazują, że człowiek od urodzenia jest „stworzeniem społecznym", a relacja między matką a dzieckiem nigdy nie stanowi niezróżnicowanej symbiozy. Warto zauważyć, że psychologia późno dostrzegła w matce samodzielny podmiot 
Centralnym problemem nie jest dla Benjamin pytanie, jak można wyjść ze stanu „niezróżnicowanej jedności”, tylko jak w ogóle możliwe jest tworzenie związków: „Większość teorii rozwojowych mocniej podkreśla autonomię jednostki niż jej relację z innymi” 33 , co badaczka tłumaczy wartością przypisywaną indywidualności w społeczeństwach Zachodu. W jej ocenie należy przyjąć inną, intersubiektywną perspektywę:

Inaczej niż w podejściu wewnątrzpsychicznym, teoria intersubiektywna stawia pytanie o procesy zachodzące między jaźnią a innymi ludźmi. O ile w podejściu wewnątrzpsychicznym indywiduum to ograniczona jednostka o złożonej strukturze wewnętrznej, o tyle teoria intersubiektywna skupia się na tych zdolnościach człowieka, które wykształcają się w interakcji jaźni z innymi. [...] Teoria intersubiektywna skłania do analizy reprezentacji jaźni oraz innych ludzi w ich różnej, a jednak współzależnej od siebie egzystencji ${ }^{34}$.

Benjamin skupia się na kategorii wzajemnego uznania, przeciwstawianej koncepcji komplementarności sadyzmu i masochizmu. Uznanie zawiera $\mathrm{w}$ sobie moment poznania, proces zaznajamiania się $\mathrm{z}$ drugim człowiekiem. Dla relacji tej oznacza to uznanie partnera za jednostkę znajdującą się poza sferą wpływów Ja, niepodporządkowaną mu i nieprzewidywalną. Uznać - znaczy zaakceptować tę różnicę, przyznać drugiej osobie prawo do niej. Wzajemne uznanie oznaczałoby zatem poskromienie dążności do obrony własnego Ja i nieodczuwanie faktu wzajemnej zależności jako zagrożenia.

Granice, które druga osoba wyznacza władczym popędom partnera, powodują u niego powstanie napięć, frustracji i narcystycznych fantazji o wszechwładzy, które Ja w najlepszym wypadku toleruje, nie ulegając zranieniu i załamaniu. Jako rekompensatę za respektowanie granic drugiej osoby Ja zyskuje jej uznanie, warunkujące ukonstytuowanie się jego podmiotowości. Punkt wyjścia refleksji Benjamin stanowi dialektyka „panowania i poddaństwa” w Heglowskiej Fenomenologii ducha, gdzie czytamy: „Samowiedza istnieje sama $w$ sobie $i$ dla siebie o tyle i dzięki temu, że istnieje [jako] sama w sobie i dla siebie dla kogoś innego; tzn. istnieje ona tylko jako coś uznanego" 35 . W interpretacji Benjamin proces wzajemnego uznania dwóch równowartych, związanych ze sobą podmiotów jest naznaczony konfliktem i przekreśla dążenie jednostki do wszechwładzy i autonomii:

- przez długi czas redukowano ją do roli „dodatku do dwumiesięcznego oseska” (J. Benjamin, Die Fesseln der Liebe..., dz. cyt., s. 20 i nast., s. 26).

33 Tamże, s. 27.

34 Tamże, s. 23.

${ }^{35}$ G.W.F. Hegel, Fenomenologia ducha, przeł. Ś.F. Nowicki, Warszawa 2002, s. 132. 
Dla Hegla, podobnie jak dla klasycznej psychoanalizy, Ja początkowo znajduje się w stanie wszechwładzy. Ja pragnie potwierdzić ten stan w spotkaniu z innym - przy czym stwierdza, że ten inny jest podobny do niego samego. Ja nie znajduje w innym potwierdzenia własnej wszechwładzy: aby tak się stało, Ja musiałoby uznać innego, co jednak oznaczałoby rezygnację z jego dążeń absolutystycznych $^{36}$.

Uzyskanie autonomii jest niemożliwe: w obronie własnej niezależności nie pomoże ani odmowa uznania drugiej osoby, ani jej zniszczenie - Ja potrzebuje bowiem potwierdzenia ze strony takiego partnera, który sam pozostaje „nietknięty”. Jedynym wyjściem, by pozostawić Ja i drugiej osobie przestrzeń i możliwość egzystencji, jest kompromis: Ja musi zrezygnować z części własnych dążeń do autonomii i uznać, że jest istotnym elementem $\mathrm{w}$ drugiej osobie. Benjamin dystansuje się wobec przekonania Hegla, iż dążenie Ja do autonomii nieuchronnie wyradza się w stosunek panowania i poddaństwa. Według amerykańskiej badaczki możliwe jest obopólne uznanie bez konieczności autodestrukcji bądź zniszczenia drugiej osoby. Uczucie jedności przy jednoczesnym rozdzieleniu jest możliwe jako relacja nieustannego napięcia, wymagająca pewnej dozy tolerancji dla frustracji.

Utrzymujące się napięcie daje podstawę wspólnym przeżyciom i wzajemnemu zrozumieniu. Natomiast fantazje, których tematem jest stopienie się w jedność i zniszczenie drugiej osoby, są wytworem rozszczepionego Ja i powodują powstanie relacji dopełnienia względem drugiej osoby - tak jak w erotyce sadomasochistycznej. Ja poszukuje miłości w komplementarnym stosunku władzy i cierpienia, w którym dominacja erotyczna wyraża pragnienie całkowitej niezależności, a erotyczna podległość - tęsknotę za wybawieniem przez drugą osobę. Taka interpretacja pozwala zrozumieć masochizm i sadyzm jako intersubiektywną strukturę niezależną od płci.

Według Benjamin źródłem każdej relacji panowania i poddaństwa jest „załamanie napięcia między jaźnią a innym”37. Sadyzm należałoby rozumieć jako zaciekłą obronę własnego Ja, masochizm - jako całkowitą zeń rezygnację: „Masochizm to nieumiejętność realizacji pragnień i aktywności własnego Ja"38. Masochizm interesuje badaczkę jako paradoksalna próba zyskania „wolności przez podległość [...] i wybawienia dzięki poddaniu się kontroli drugiej osoby”39. Zawiera on w sobie „osobliwie zdeformowane pragnienie uznania” i można go rozumieć jako wyraz nieuda-

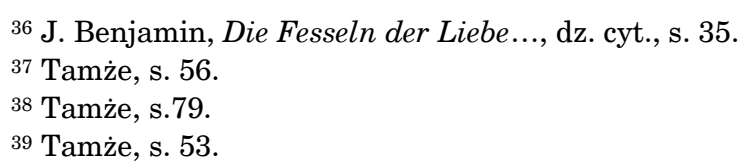


nej indywiduacji, w której obecna jest tęsknota, by „w końcu odnaleźć niepoznaną jaźń”. Znoszenie bólu, podporządkowanie - to próba rezygnacji z różnicy względem drugiej osoby i z oddzielenia się od niej; to cena, którą trzeba zapłacić za ucieczkę przed lękiem, jaki budzi perspektywa oderwania się od jednostki silniejszej, nieledwie boskiej.

W analizie masochistycznej powieści Pauline Réage Historia O., znacznie bardziej drastycznej niż teksty Sacher-Masocha, Benjamin opisuje doświadczenie transcendencji, jakie staje się udziałem głównej bohaterki w jej dobrowolnej erotycznej niewoli:

Jej kochanek jest kimś w rodzaju boga; bohaterka może zaspokoić swoje pożądanie, wyłącznie okazując mu posłuszeństwo. Staje się instrumentem jego nadrzędnej woli, co umożliwia jej osiągnięcie stanu transcendencji. Historia O., tematyzująca poddanie i transcendencję, przypomina upokorzenia doznawane przez świętych: tortury i pohańbienie, na jakie skazuje się bohaterka, to rodzaj męczeństwa; bohaterka poniekąd wierzy nawet, że w ten sposób odpokutuje swe winy ${ }^{40}$.

$\mathrm{Na}$ analogię między strukturą masochizmu a religią zwraca uwagę Theodor Reik, widząc w „kulturowym masochizmie” drastyczne przeciwstawienie dwóch skrajności: boskiej wszechwładzy i ludzkiej niemocy.

Model ten jest w pewnym sensie słuszny, dlatego logiczne wydaje się pytanie Benjamin, na ile „produktywna” jest teza o komplementarności omnipotencji i niemocy. Jej odpowiedź brzmi: komplementarność owa chroni jaźń, co pokazują typowe historie indywidualnego rozwoju sprzyjające wytworzeniu sadystycznych i masochistycznych struktur osobowościowych.

Postawa sadystyczna jest odpowiednikiem dziecięcego dylematu, jaki powstaje, gdy rodzice nie potrafią postawić granicy dziecięcym żądaniom i fantazjom o wszechmocy. Bezsilność rodziców budzi w dziecku poczucie egzystencjalnego zagubienia [...]. Człowiek o charakterze sadystycznym próbuje więc dotrzeć do drugiej osoby (,innego"), aby odnaleźć siebie samego w granicy wyznaczonej przez partnera. Rodzice, którzy jako ci „inni" powinni byli ową granicę wytyczyć, zawiedli; jednak nawet masochistyczny partner nie rozwiąże problemu poszukiwania własnego Ja.

Odwrotnie postawa masochistyczna: jej źródłem jest sytuacja, gdy rodzice karzą dziecko i odwracają się od niego. W takim układzie dziecko nie ma prawa do własnych granic; jest poddawane ciągłej kontroli i karom, jego Ja jest nieustannie naruszane, w związku z czym dziecko nie może się sprawdzić w roli samodzielnie działającego podmiotu. Agresja, która pomogłaby mu natrafić na granice u innych osób i określić w ten sposób swoje miejsce w świecie, jest natychmiast karana, a dziecko kieru-

40 Tamże, s. 61. 
je ją przeciwko sobie: „Dziecko masochistyczne traci wszelką nadzieję, że kiedykolwiek zostanie uznane przez innych. Nie może liczyć, że znajdzie oparcie w świadomości innych"41.

Postać sadystycznego władcy to dla osobowości masochistycznej symbol kontroli, władzy i ochrony - tego, czego masochista nie potrafił zintegrować. I nawet w doznawanym cierpieniu odbiera on partnera-sadystę jako „autorytet” gwarantujący ochronę. Sadysta stanowi dla masochisty projekcję jego wszechmocy i zaprzeczenie bezradności, swoisty zbiornik „odrzuconych” aspektów osobowości. W postawie masochistycznej kryje się tęsknota za przestrzenią, w której stłamszone Ja z dzieciństwa można porzucić i stworzyć na nowo.

Interakcja sadyzmu i masochizmu może ukonstytuować wspólną rzeczywistość i przestrzeń kompensacyjną dla doświadczenia braku granic. Jednak ze względu na swą skrajność obie postawy skazane są na klęskę.

Podział ról między podmiot docierający do innego i ten, który pozwala do siebie dotrzeć, prowadzi - jeśli ma być konsekwentny - do śmierci albo porzucenia, reprodukując tę samą pustkę, samotność i opuszczenie, z których powstał. Masochiście grozi utrata własnego Ja generująca depresję i pustkę, sadyście - utrata partnera przez jego deprecjację, a w efekcie samotność.

Zaproponowany przez Benjamin model równowagi między obroną własnego Ja a uznaniem - struktura wykluczająca stosunek panowania i poddaństwa - pokazuje wyjście $\mathrm{z}$ fatalistycznych konsekwencji, o których mówili frankfurccy mistrzowie amerykańskiej badaczki: Adorno i Horkheimer. Obaj filozofowie pojmują zjawisko władzy jako ostateczny i nieunikniony rezultat oświecenia, żądającego autonomii i jej sprzyjającego ${ }^{42}$.

41 Tamże, s. 72.

${ }^{42} \mathrm{~W}$ ujęciu Horkheimera i Adorna sadystyczna władza nie wiąże się z popędem seksualnym. Obaj badacze widzą w tej formie rządów ostateczny skutek rozwoju oświeconego rozumu. W Dialektyce oświecenia w jednym ze szkiców (Julia albo oświecenie i moralność) autorzy odczytują powieść de Sade'a Histoire de Juliette w kontekście filozofii Kanta. Zwracają uwagę na ambiwalencję kantowskiego rozumu, który z jednej strony ma charakter utopijny, ponieważ jest wcieleniem tego, co ogólne (ponadindywidualne) i potrafi wytworzyć intersubiektywność. Z drugiej strony wobec faktu, że owa ogólność da się utrzymać tylko na płaszczyźnie transcendentalnej, natomiast na płaszczyźnie empirycznej o działaniu decydują sprzeczności interesów, należałoby mówić o rozumie instrumentalnym (termin Horkheimera), który steruje tymi interesami pod postacią racjonalizmu. Celem rozu$\mathrm{mu}$ instrumentalnego byłoby przeforsowanie interesów partykularnych: ,jedyną jego funkcją jest spreparowanie przedmiotu tak, by materiał zmysłowy stał się materiałem ujarzmienia”. (M. Horkheimer, T.W. Adorno, Dialektyka oświecenia, przeł. M. Łukasiewicz; przekład przejrzał i posłowiem opatrzył M.J. Siemek, Warszawa 1994, s. 101). Osobistą autonomię, postulowaną przez Kanta jako nadrzędny cel oświecenia - zdolność człowieka do „posługiwania się własnym intelektem bez obcego kierownictwa” (Dialektyka 
Przekonanie, że libido to popęd dążący do ukonstytuowania relacji równości i uznania wobec drugiej osoby, należy jednak zasadniczo zakwestionować - tak samo jak utopijną wizję rozumu, z którego rzekomo wypływa równość i sprawiedliwość. Wydaje się, że model homeostatycznego zachowania granic własnego Ja i granic drugiego człowieka, postulowany przez Benjamin jako zdrowa forma relacji podmiotowo-przedmiotowej, to raczej wyjątek niż reguła - podobnie jak rozum, rzekomo oparty na równości i równość generujący, jedynie w rzadkich przypadkach pozwala człowiekowi działać bez nadużywania władzy. Wydaje się, że zarówno w rozumie, jak i w libido kryją się tendencje (auto)destrukcyjne.

\section{Księga: opowieść o transcendencji}

[...] Opowiadanie Księga staje się pre-tekstem dla doświadczenia nieopisywalnego, którego ślady odciśnięte są w tekście. Przywoływana „rzecz bez miary”, „Świetność bez rachuby”43 jest aluzją do Kantowskiej „rzeczy samej w sobie”. Narrator rezygnuje z jej dalszych opisów: Księga to po

oświecenia, dz. cyt., s. 98) - Horkheimer i Adorno badają sceptycznie pod kątem wciąż ponawianego żądania o równość i sprawiedliwość, implikowaną tym pojęciem. Uważają, że autonomię tę Kant sformułował zbyt formalnie, dlatego w jej skrajnej formie - jako spotęgowanie zasady scjentyficznej „do tego stopnia, że przerasta w destrukcję” (Dialektyka oświecenia, dz. cyt., s. 111) - można ją odnaleźć również w utworach de Sade'a; autor ten bowiem nie skonstruował nic innego, jak tylko „uwolniony od kurateli mieszczański podmiot” (Dialektyka oświecenia, dz. cyt., s. 104). Samoopanowanie i władzę nad innym można pogodzić tak, by nie były ze sobą sprzeczne. Julia de Sade’a ucieleśnia doskonałą władzę człowieka nad samym sobą, co implikuje emocjonalną apatię i krańcowy racjonalizm. Sade, spełniając w swoich tekstach te założenia formalne, które Kant postuluje jako warunki umożliwiające istnienie jego „państwa celów” (w szczególności odrzucenie etyki afektów), aby następnie mimo tego zamienić imperatyw kategoryczny w jego przeciwieństwo („radykalne zło"), zaprzecza idei formalnej konieczności, zgodnie z którą już sam intelektualny wgląd w prawo moralne powinien zaowocować dobrem. Ten despotyzm etyki oświeceniowej prowadzi Horkheimera i Adorna do radykalnej tezy przeczącej krytyce praktycznego rozumu: otóż „na gruncie rozumu nie da się przedstawić zasadniczego argumentu przeciw zabijaniu" (Dialektyka oświecenia, dz. cyt., s. 137). Oznacza to także, iż wartość etyczna rozumu nie wynika z niego samego. Obaj filozofowie nie biorą myślicielom „sadystycznym” (do których zaliczają również Nietzschego) za złe, że udało im się udowodnić, iż konsekwentny racjonalizm zasadza się na tożsamości władzy i rozumu, a więc w sadystycznym sposobie myślenia dochodzi do głosu wyparta prawda rozumu. Władza taka nie liczy się z uczuciami innych, nie usprawiedliwia się w sposób intersubiektywny, tylko ślepo forsuje interesy, kierując się racjonalizmem i skutecznością. Horkheimer i Adorno lekceważą utopijny wymiar kantyzmu - co nietrudno wytłumaczyć historycznym doświadczeniem antysemityzmu i Holocaustu, które w potworny sposób udowodniły barbarzyńskie skłonności społeczeństwa racjonalistycznego.

43 Zob. Schulz, Opowiadania..., dz. cyt., s. 105. 
prostu „cicha kapitulacja przed nieobjętością transcendentu”44. Księga nawiązuje do tajemnicy, którą można dzielić ( $w$ doświadczeniu), ale nie można jej nazwać. Jej znaczenie objawia się w komunikacji innego rodzaju niż semantyczny przekaz.

Skoro „rzecz” jest nienazwana, narrator wykorzystuje pośrednie możliwości języka i ucieka się do świata fantazji. Sugeruje przejście w sferę bezpośredniego kontaktu: gdy spojrzy czytelnikowi „głęboko w oczy”, ma w nich „zalśnić blask” tak zbawienny, że odbiorca zagłębi się w medytację pełną zrozumienia. Kto podda się temu działaniu, jest prawdziwym czytelnikiem, „na jakiego liczy ta powieśc”45 - idealnym słuchaczem, skupiającym uwagę na wszystkich poziomach poznania zmysłowego.

Ukazana w tekście fizyczna obecność narratora-mówcy pozwala mu wytworzyć współczująca formę zrozumienia, którą może przenieść na sytuację lektury. Opowiadanie zakłada ukrytą, lecz jasną dla obu stron wspólnotę doświadczenia między czytelnikiem a pisarzem: „Bo czyż pod stołem, który nas dzieli, nie trzymamy się wszyscy tajnie za ręce?”46.

Te porozumiewawcze spojrzenia i potajemny uścisk rąk - doświadczenie jedności - nie mogły być ukazane w Xiędze bałwochwalczej, która kieruje uwagę widza raczej na brak porozumienia. I dlatego właśnie opowiadanie Księga, również opisujące historię utraty i degradacji, zdaje się uzupełniać odczytanie treści Xięgi wykraczających poza to, co w niej przedstawione: nieprzypadkowo następne opowiadanie to Genialna epoka.

Taką tezę potwierdzałaby m.in. obserwacja, że tytuły obu utworów przywołują szczególne, sakralne znaczenie słowa księga - nawet jeśli w tytule opowiadania brak efektu obcości wywołanego nietypową pisownią. [...] Za sprawą metaforycznego ładunku słowa księga zwykłe książki powiązane zostają ze sferą profanum. [...] Księga to dla Schulza uniwersalna metafora, roszcząca sobie prawo do ogarnięcia wszystkich logicznych możliwości istnienia i ekspresji. Księga to znak doskonałości i zrozumienia, a tym samym punkt odniesienia do tego, co nieobecne. W opowiadaniu Józef kompensuje doświadczenie utraty za pomocą dwóch strategii. Z jednej strony uprawia własną twórczość, obiektywizując swą pasję w rysunkach; z drugiej - odnajduje w sferze „niskiej”, w szpargale wyniesionym do rangi Autentyku, szczególną formę lektury, odkrywającą w nim ślady pierwotnej jedności. Ten szczególny sposób czytania, do którego nawiązuje narrator $\mathrm{w}$ swym apelu do czytelnika, obiecuje życzliwe zrozumienie dla „zdegradowanych, zawiedzionych”, współczujący ból

\footnotetext{
44 Tamże.

45 Tamże.

46 Tamże.
} 
i ekstatyczne aluzje do sensu nieobecnego, ale objawiającego się w drobnych znakach. Czy takiej lektury nie zapowiadała już Xięga bałwochwalcza?

\section{Związki Księgi z Xięgą bałwochwalczą}

[...] Metafora „ułamków zwierciadła”, odsyłajacych do całości, odnosi się również do Xięgi bałwochwalczej. Cykl ten, posługujący się masochistyczną matryca, pokazuje niemożność samopoznania, do którego normalnie można dojść, „przeglądając się” w komunikacji z innymi. Taki sposób odczytania potwierdza opowiadanie Księga: narrator twierdzi, że jego wspomnienie Autentyku pochodzi z czasów, kiedy „matki jeszcze nie było” - co oznacza, że „brak” (nieobecność) powstaje wskutek rozmijających się spojrzeń. [...]

Schulzowi jako artyście chodzi o to, by pozbierać „ułamki zwierciadła" - najróżniejsze książki - i na ich podstawie zrekonstruować Autentyk. Jednym z sensów zapisanych w Xiędze bałwochwalczej byłaby zatem dokumentacja klęski aktu stworzenia, względnie pokazanie miejsca, w którym skończyła się Księga Stworzenia. Xięgę należałoby też rozumieć jako krytykę - ubolewanie nad faktem, że doskonałość wciąż nie jest pełna.

Jak wspomniano, ów brak sygnalizowany w obrazach bólu może się wiązać z wypartym, zakazanym ideałem relacji z drugim człowiekiem: w Xiędze brak bowiem opiekuńczej, macierzyńskiej kobiety, brak przedstawienia symbiozy.

Taka wizja ulega sublimacji w opisanym wyżej doświadczeniu jedności z opowiadania Księga, gdzie przybiera postać porozumienia bez słów, generowanego przez spojrzenie. Doświadczenie egzystencjalnej samotności wiedzie prosto ku nieznośnemu kryzysowi, który można przezwyciężyć dzięki fantazji, działalności twórczej i utożsamieniu z drugą osobą. Skoro więc Xięga ilustruje ową samotność wśród natury, wyobcowanie przez erotykę (która zawsze obiecuje zbawienie), to opowiadanie mówi o symbolicznej alienacji na wyższym poziomie: o zapomnieniu i utracie stanu pierwotnego - „genialnej epoki”, która jednak skrycie obecna jest „w każdym z nas".

Masochizm naznaczony jest paradoksem: źródło cierpienia jest równocześnie źródłem zbawienia. Cierpienie, powracające nieustannie w obrazach samotności, Schulz wykorzystuje w Xiędze we wszystkich wariantach i do granic możliwości. Podobnie eksploatuje swój autoportret, odczłowieczając go - podczas gdy obiekt miłości zostaje wywyższony 
i udramatyzowany. Ujarzmienie wizji, nadanie im formy ${ }^{47}$, obdarzenie ich cechą przedstawialności - wszystko to odbiera obiektowi jego grozę. Maszkary, o których mówi Józef w Genialnej epoce, pokazują się widzowi w postaci papierowych rysunków. Zmysł wzroku, ujarzmiający przedmioty, wskazuje patrzącemu - którym staje się również sam Schulz, „skanując" swój obiekt - wyjście z kryzysu monstrualności.

Takim właśnie „ciepłym” spojrzeniem obdarza czytelnika Schulz, pisząc: „spojrzę [mu] głęboko w oczy i na dnie samym zalśnię tym blaskiem. W tym krótkim a mocnym spojrzeniu [...] pochwyci on, przejmie, odpozna". Takim wzrokiem patrzą na siebie zakochani - wzrokiem wprawiającym w stan szaleństwa; mówił o tym już Platon, a potwierdza to dzisiejsza neuropsychologia; spojrzenie takie wyzwala przemożną potrzebę wybawienia.

Dehumanizacja stosunków między dwojgiem ludzi w Xiędze bałwochwalczej powoduje u odbiorcy niepokój. Za tą odczłowieczoną wizją kryje się [...] tęsknota za stopieniem w jedno $\mathrm{z}$ obiektem miłości - tęsknota do stanu niemożliwego, objętego tak rygorystycznym zakazem, że da się on przedstawić wyłącznie w formie własnej negacji. Za Jessiką Benjamin można powtórzyć, że źródłem cierpienia w Schulzowskich scenariuszach (braku) relacji międzyludzkich jest załamanie napięcia między uznaniem a obroną własnego Ja; za psychoanalitykiem Masudem Khanem - że już w tej erotycznej skrajności uwidacznia się alienacja.

\section{Autentyk i jego ślady w odpadkach}

[...] Pomysł, by potraktować Schulza jako pisarza alienacji, nie jest nowy ${ }^{48}$. Nie powinna więc dziwić myśl, że jest on twórcą grafik „alienacyjnych”. Schulzowskie ujęcie problematyki mitu pozwala stwierdzić, że pisarz przyłącza się do krytyków kultury i cywilizacji z przełomu wieków, wypróbowuje alternatywy wobec lęków przed zagładą świata, reaguje na kryzys grożącej dehumanizacji. Swoją optymistyczną wizję rehumanizacji wiąże z możliwościami sztuki, zwłaszcza z symbolicznym wymiarem języka. Mimo to Schulz nie widzi ratunku poprzez sztukę, a jedynie skoncentrowany w niej opór i sprzeciw.

Bezsilność w obliczu rozpętanej agresji i jej władczych uroszczeń negujących życie ma dla Schulza charakter totalny. To jednak niemoc różna

${ }^{47} \mathrm{~W}$ opisie procesu twórczego w Genialnej epoce mowa jest o „rupieciarni form” (zob. B. Schulz, Opowiadania ..., dz. cyt., s. 125).

48 Zob. W. Wyskiel, Inna twarz Hioba. Problematyka alienacyjna $w$ dziele Brunona Schulza, Kraków 1980; C. Karkowski, Kultura i krytyka inteligencji w twórczości Brunona Schulza, Wrocław 1979. 
od tej przeżywanej „tylko” przez alienację: z wyobcowania zawsze bowiem mogą powstać fantazje, wizje jakiegoś wyjścia, jakiegoś wybawienia - czy to retrospektywne (mit), czy to prospektywne (utopia). Dla Masuda Khana, który nawiązuje do psychoanalityka Edwarda Glovera, wykształcenie perwersji to nie tylko wyraz wyobcowania własnej jaźni, ale jednocześnie próba wyzwolenia się z niemocy zagrażającej Ja. Już Gloverowska teoria seksualizacji lęku czy też obrony przed nim za sprawą perwersji ${ }^{49}$ nasuwa myśl, że w koncentracji na erotyce kryje się chęć ochronienia własnej jaźni. Według Khana „masochizm to szczególny wariant maniakalnej obrony, do której ucieka się Ja, aby uchronić jaźń przed psychicznym bólem grożącym unicestwieniem jaźni, a więc i samego Ja"50.

Przedstawienie masochizmu w dziele sztuki jeszcze dalej odsuwa ów psychiczny ból. Alienacja ma tu podwójny wymiar. Z jednej strony oznacza wyobcowanie niebezpiecznych treści w przeżyciu psychicznym, a zatem dokonany już akt wybawienia. Z drugiej strony opisuje „oddalenie” od mglistego ideału doświadczenia jedności. Jak wspomniano, ideał ten Schulz przedstawia w swych grafikach wyłącznie w drodze negacji: w idolizacji postaci kobiecych jedność owa jawi się jako coś zakazanego, sfera zmysłowa staje się nietykalną świętością, a demonizacja erotyzmu zamienia ją w koszmar.

Nasuwa się następująca teza: w Xiędze bałwochwalczej postacie kobiece, ból i pragnienie symbiotyczno-chroniącej jedności podlegają idolizacji i demonizacji (rozumianej jako podwójna negacja); w opowiadaniu Księga zabiegowi temu odpowiada - ironicznie przełamana - funkcja szpargału-Autentyku. Płaszczyzna symboliczna masochizmu koreluje z symbolem Autentyku. Płaszczyzny te jawią się jako negacja tego, co dane: negacja komercyjnej reklamy i zaprzeczenie cielesności w związku masochistycznym. [...]

\section{Ilustracje do opowiadania Księga}

W pierwszym wydaniu Sanatorium pod Klepsydra Schulz opatrzył opowiadanie Księga rysunkami, które (tylko) na pierwszy rzut oka niewiele mają wspólnego z Xięga bałwochwalcza. Obydwa podejmują motyw kataryniarza obecny w tekście ${ }^{51}$. Pierwsza ilustracja przedstawia cztery osoby, wśród nich kataryniarza: brodatą postać odzianą w luźne szaty.

49 Zob. E. Roudinesco, Wörterbuch der Psychoanalyse, Wien 2004, s. 533 i nast.

50 M. Khan, Entfremdung bei Perversionen, Frankfurt am Main 1989, s. 304.

51 Rysunki te można znaleźć np. w albumie Bruno Schulz, red. J. Koźbiel (Wydawnictwo BOSZ, Olszanica 2003), s. 75 (pierwsza z omawianych ilustracji) i s. 74 (drugi rysunek, którego opis pominięto w tłumaczeniu) - przyp. tłum. 
Tuż nad nim na balkonie stoją trzy pozostałe osoby. [...] Naga figura dziecka o nieproporcjonalnie dużej głowie opiera się o balustradę, uśmiechnięta, jej oczy z profilu sprawiają wrażenie zadumanych, nie patrzą w żaden określony punkt. $\mathrm{Z}$ tyłu stoi mężczyzna w garniturze, o twarzy Schulza. [...]

Postać kobiety umieszczona jest wprawdzie tuż obok figur męskich, jednak odgraniczona od nich: stoi w najdalszym, prawym rogu balkonu. Jej prawa ręka spoczywa na balustradzie. Kobieta ma na sobie prostą sukienkę i buty na wysokich obcasach. Głowę trzyma pochyloną. Lewą rękę przykłada do klatki piersiowej - gest, który wraz z pochyleniem głowy często pojawia się w Xiędze bałwochwalczej. Jej twarz wyraża radość - w szerokim rozumieniu, bo trudno odróżnić, czy jest to radosna kontemplacja, skrywana ironia i drwina, czy też pogodne rozmarzenie. Przy bliższym wejrzeniu okazuje się, że wzrok kataryniarza utkwiony jest w tej właśnie kobiecie. Jego zmarszczone czoło, opuszczone kąciki ust wyrażają żarliwą pasję. Lewa noga jest wysunięta do przodu i lekko zgięta w kolanie. Rysunek ten zawiera aluzje to Xięgi bałwochwalczej; podobnie jak tam, tu również brak bezpośredniego kontaktu wzrokowego między postaciami, które stoją każda z osobna. A jednak muzyka katarynki wytwarza więź między nimi. Automat wygrywa melodie szlagierów, w których skondensowana jest sentymentalna tęsknota miłosna. Szlagiery te nawiązują do minnesangu i stwarzają sytuację analogiczną do tej, w której szpargał stał się Autentykiem: kataryniarz przekształca się $\mathrm{w}$ trubadura, dama w swych fantazjach wznosi się na narcystyczny piedestał, balkon staje się zamkową komnatą. Przepaść między rycerzem i damą jest nie do przezwyciężenia w wymiarze libidynalnym. Oboje łączy jedynie mglista fantazja: ze strony kobiety marzenie o byciu obiektem pożądania, ze strony mężczyzny - wizja beznadziejnego pożądania, braku uznania przez wyimaginowaną partnerkę. [...]

Dlaczego Schulz zilustrował akurat motyw kataryniarza, wybierając go z kompleksu metafor zawartych w opowiadaniu Księga? Co więcej: dlaczego od razu w dwóch wariantach, choć przecież w tekście znaleźć można wiele innych motywów nadających się do zilustrowania? Czemu Schulz nie zainspirował się np. postacią demonicznej Magdy Wang?

$\mathrm{W}$ rezygnacji artysty z wykorzystania innych wątków można widzieć potwierdzenie tezy, że nie chodzi mu tym razem o erotyczno-pornograficzną stronę męskiego masochizmu, lecz o izolację, emocjonalne ubóstwo i chłód w stosunkach międzyludzkich. Ukazana na obu rysunkach relacja między matką a synem uzupełnia to, czego w Xiędze można się było domyślać: brakujący, nieprzedstawiony moment ukrytej tęsknoty. Ta jedność matki i dziecka - chroniąca, ciepła symbioza - znajduje subtelny 
wyraz w drugiej ilustracji: obie postacie są uśmiechnięte, stoją tuż koło siebie, dziecko przytula głowę do ramienia matki.

Zniszczenie tej ochrony i symbiotycznego poczucia bezpieczeństwa reprezentują postacie żebraków. Pierwszy rysunek przywołuje sekretne porozumienie między autorem a czytelnikiem z Księgi i pokazuje - za pośrednictwem autoportretu Schulza - znaczące, głębokie spojrzenie, o którym mowa na początku opowiadania - tak, jakby Schulz chciał powiedzieć: „To właśnie to, o co mi chodzi”.

Ilustracja z kataryniarzem ma głęboki wymiar, który również spaja opowiadanie Księga z grafikami Xięgi bałwochwalczej. Mimo to jedno wciąż pozostaje niejasne. Warto $\mathrm{w}$ tym miejscu przytoczyć cytowane wielokrotnie zdanie $\mathrm{z}$ listu do Witkacego, gdzie Schulz wypowiada się o związkach między swoimi tekstami a twórczością plastyczną: „Na pytanie, czy w rysunkach moich przejawia się ten sam wątek, co w prozie, odpowiedziałbym twierdząco. Jest to ta sama rzeczywistość, tylko różne jej wycinki" 52 .

Jaka to jest rzeczywistość? W moim przekonaniu chodzi w niej zawsze o skoncentrowane doświadczenie społeczne i intelektualne, które być może da się odsłonić w interpretacji - zawsze wątpliwej, bo zmąconej własnym doświadczeniem.

Fetyszystyczny charakter towarów i obietnice zbawienia przez reklamę [motywy z opowiadania Ksiegga - przyp. tłum.] badano wystarczająco często. Opowiadania i grafiki Schulza - mimo iż można w nich rozpoznać owe znane toposy krytyki kultury - są pełne przekory. To, co wyraża się w symbolach i może powodować dezorientację, to roszczenie o transcendencję, utrzymane $\mathrm{w}$ mocy nawet przy najgłębszym pesymizmie. Schulz wybiera masochizm jako formę wyrazu, aby ukształtować własne doświadczenia - w ten sposób, że przesyca je elementami masochistycznymi, a w końcu rozsadza $\mathrm{w}$ artystycznym przedstawieniu. W zjawisku masochizmu kryje się choroba czasu i choroba Ja, a także tęsknota za ich uleczeniem. Pod postacią jednoznaczności i rozszczepienia Schulz gromadzi w swej Księdze najrozmaitsze doświadczenia bólu, cierpienia, rozbicia, przemocy społecznej. Jego opowiadania nie tyle realizują masochistyczny schemat na płaszczyźnie fizycznej, ile tematyzują kryzys egzystencjalny, kruchość ludzkiego istnienia i nieuchronność śmierci, zawsze o włos tylko rozmijając się z doświadczeniem jedności.

przełożyła Katarzyna Lukas

52 B. Schulz, Opowiadania ..., dz. cyt., s. 443. 